\title{
Nuove prospettive sulla ferrovia Circumetnea: un viaggio tra archivi e rappresentazione digitale
}

\author{
Raissa Garozzo \\ Cettina Santagati
}

Abstract

Le reti ferroviarie, elementi di connessione tra uomini e territori, sono frutto dell'ingegno e delle innovazioni tecnologiche di fine Ottocento. Simbolo di una modalità di trasporto che restituisce al viaggiatore la dimensione dell'attraversamento dello spazio e del tempo per raggiungere la destinazione, esse segnano con il loro tracciato il paesaggio italiano, integrandosi nel contesto ambientale. Le opere di ingegneria (ponti e gallerie) e gli edifici di servizio (stazioni, caselli, garitte di guardia e magazzini) ad esse connesse costituiscono degli "iconemi" del paesaggio, punti di riferimento nell'immaginario collettivo. Lo studio indaga, attraverso gli strumenti del rilievo e dell'indagine critica, il tracciato e le opere di ingegneria della ferrovia Circumetnea, unica ferrovia a scartamento ridotto ancora in esercizio in Sicilia che collega Catania a Riposto attraversando diversi centri pedemontani etnei. Realizzata a fine Ottocento per supportare le dinamiche economiche del settore agricolo e manifatturiero dell'areale etneo, è testimonianza di conoscenze teoriche e abilità costruttive del passato, dell'uso sapiente e sostenibile dei materiali della tradizione locale. Lo studio proposto si pone l'obiettivo di analizzare la ferrovia Circumetnea attraverso il censimento, la classificazione e la documentazione delle opere ad essa correlate, in una prospettiva di conoscenza, conservazione e valorizzazione.

Parole chiave

ponti in muratura; caselli ferroviari; archeologia industriale; ricerca archivistica; rilievo digitale.

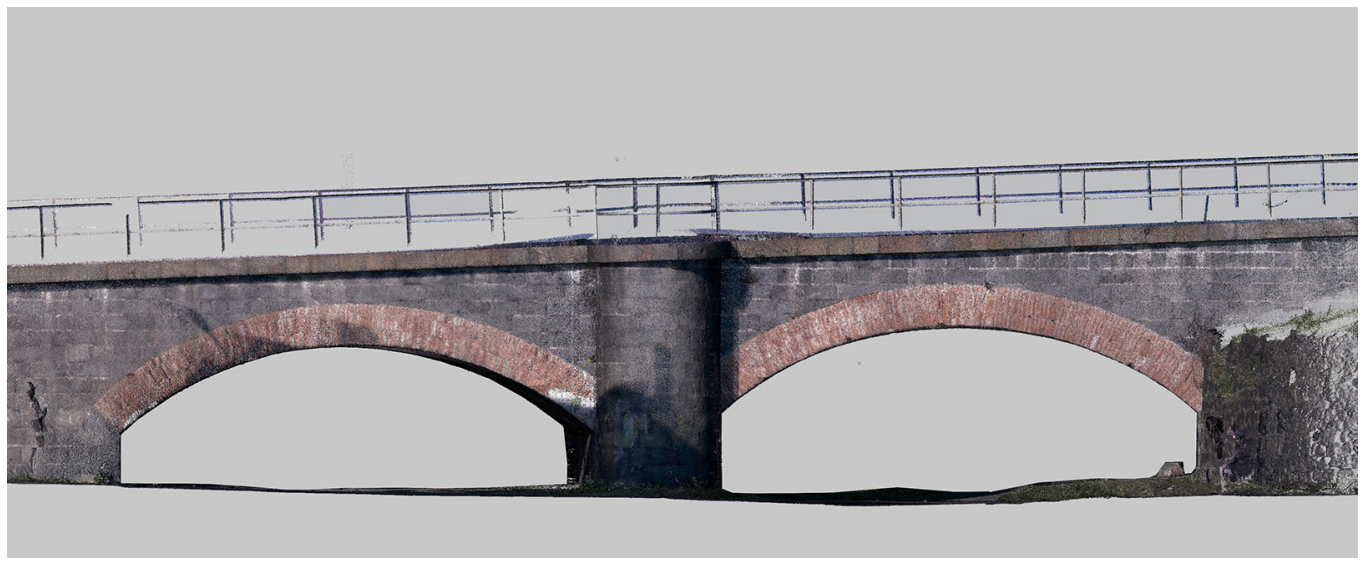




\section{Introduzione}

La rete ferroviaria siciliana è un patrimonio chiave costituito da sedimi continui che connettono città e borghi, intervallati da opere di ingegneria civile, quali ponti e gallerie, e da edifici, come stazioni, caselli, garitte di guardia e magazzini. Parte di questo patrimonio, testimonianza di un capitolo importante della storia della Sicilia post-industriale, versa oggi in stato di abbandono. Poco rimane, infatti, della capillare rete ferroviaria Siciliana composta da linee a scartamento normale e ridotto, il cui slancio realizzativo va individuato nell'importanza dei bacini di zolfo dell'isola e nelle istanze provenienti dai settori imprenditoriali agricoli, industriali e manifatturieri di fine Ottocento.

Lo sviluppo dell'industria automobilistica e l'aumento del tasso di motorizzazione individuale hanno portato alla dismissione e al conseguente deterioramento delle linee ferroviarie a scartamento ridotto presenti sul territorio Siciliano, ad eccezione della Circumetnea, unica ferrovia di questo tipo ancora in servizio. Realizzata tra il 1889 e il 1895 per supportare le dinamiche economiche del settore agricolo e manifatturiero dell'areale etneo, la Circumetnea collega Catania a Riposto, compiendo il periplo dell'Etna e attraversando diversi centri pedemontani etnei. Oggi è uno dei modi più suggestivi per esplorare il territorio etneo, con il suo lento incedere tra centri urbani, borghi, vigneti e paesaggi lavici (fig. I).

Ad eccezione della tratta che va da Catania a Biancavilla, che nel tempo ha subito modifiche significative, la Circumetnea conserva i caratteri progettuali originali. I ponti, le gallerie e gli edifici che marcano il suo percorso, testimonianze di conoscenze teoriche e abilità costruttive del passato, sono diventati nel tempo parte del paesaggio nel quale sono inseriti; l'uso di materiali della tradizione locale, come la pietra lavica, li ha resi inoltre elementi distintivi della linea ferrata etnea. L'indubbio valore identitario di tali manufatti, 'iconemi' del paesaggio e punti di riferimento nell'immaginario collettivo, emerge nei tratti distintivi e nell'utilizzo dei materiali del luogo, che li rendono un unicum nel panorama isolano.

Nonostante ciò, si tratta di un patrimonio a rischio: ponti e gallerie, per le mutate esigenze di viabilità e l'inevitabile espansione urbana, rischiano di essere demoliti; garitte di guardia, caselli e stazioni, non più in uso, sono soggetti a naturale obsolescenza a causa dell'incuria e dell'assenza di manutenzione.

Date queste premesse, lo studio proposto si pone l'obiettivo di analizzare la ferrovia Circumetnea attraverso le opere ad essa correlate, in una prospettiva di conoscenza, conservazione e valorizzazione.

A tal fine si è proceduto alla raccolta, all'analisi e al confronto della documentazione d'archivio, della cartografia storica, dei rilievi digitali, riconnettendo il passato e il presente della Circumetnea.

Lo studio delle configurazioni geometriche, delle tecniche costruttive e delle ragioni del progetto insieme all'utilizzo degli strumenti di indagine della rappresentazione digitale e del rilievo, è certamente il punto d'inizio per tutelare una testimonianza parte del patrimonio archeologico industriale siciliano che sta suscitando un rinnovato interesse nella comunità scientifica.

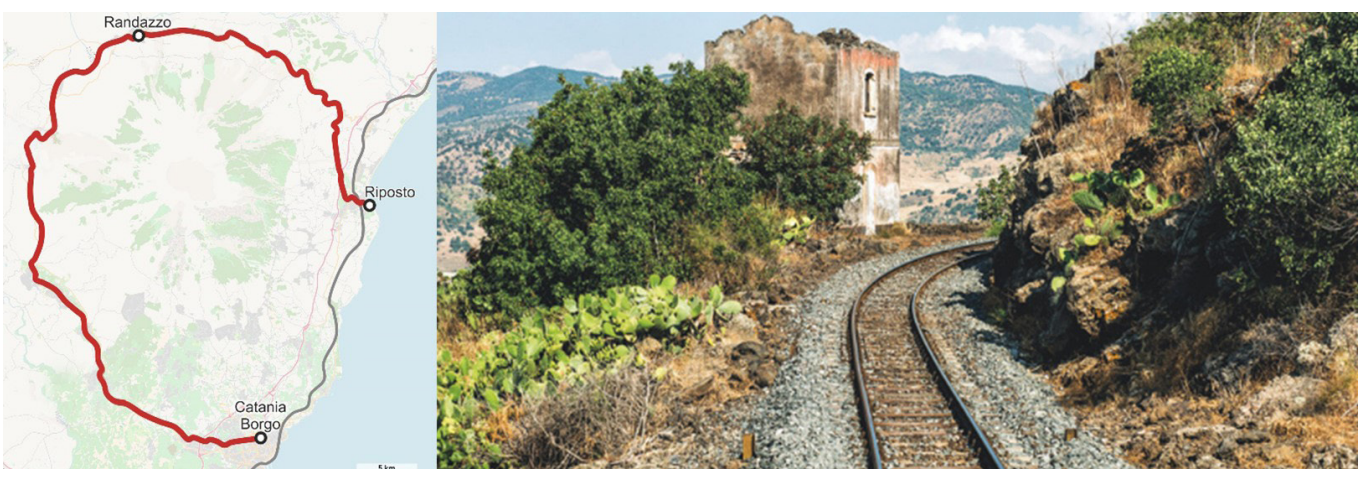




\section{Il paesaggio ferroviario e le sue infrastrutture}

Che si tratti del recupero di tracciati ferroviari dismessi mediante la creazione di parchi lineari e percorsi naturalistici [Cresta 2019; Dal Sasso 20 12; Oppido 2020] o della valorizzazione di linee dall'incedere lento realizzate in contesti dall'orografia articolata [Battino 20 I8; Pavletits 202I; Petino 20 I8], l'azione progettuale su contesti ferroviari storici non necessita di nuove infrastrutture, ma può utilizzare il vasto patrimonio esistente, in un'ottica di riuso e sostenibilità. I caselli ferroviari, a disposizione del casellante e della sua famiglia per consentire il controllo ininterrotto della linea, sono i segni tangibili di un passato concluso recentemente [Vaschetto 20 17] il cui recupero, che parte dalla conoscenza e dal rilievo dei manufatti, può creare un sistema virtuoso di relazioni tra contesto e patrimonio preesistente [Moschella 2017; Tomasetti 2020].

Interventi di tipo conservativo e progettuale necessitano, dunque, di un'attenzione multidisciplinare, in cui un percorso conoscitivo per livelli progressivi di approfondimento è fondamentale.

L'architettura dei ponti in muratura è particolarmente significativa per una lettura e una rappresentazione del territorio, soprattutto dal punto di vista percettivo [Bonanno 1999]. Sebbene il disegno dal vero sia strumento privilegiato in tal senso [Manganaro $20 \mathrm{I} \mathrm{I}$ ], nell'analisi del sistema ponte-territorio e nella riproduzione digitale del manufatto, la nuvola di punti ha un vasto potenziale e si presta a molteplici campi di applicazione. In Damiata [Damiata 20 I 4 l la nuvola da fotogrammetria è utilizzata, ad esempio, per l'analisi 'stereotomica' di un ponte diagonale; in León-Robles [León-Robles 20 I9] la ricerca storico-archivistica e rilievo digitale vengono utilizzati come base-dati per la creazione di Historical Bridge Information Models (HBrIM). Sánchez-Rodríguez [Sánchez-Rodríguez 20I8] introducono, invece, una nuova metodologia per l'elaborazione automatizzata di grandi nuvole di punti per la diagnosi di patologie strutturali nei ponti in muratura. In Savini [Savini 202I] viene sottolineata l'importanza di un approccio integrato per la conoscenza delle caratteristiche tecnologiche e strutturali dei ponti in muratura applicando il metodo stratigrafico archeologico e una gestione $3 d$ dei dati a partire dal rilievo digitale.

Risulta evidente come l'analisi storico-critica e del progetto originario insieme al rilievo geometrico-strutturale delle opere d'arte ferroviarie è indispensabile per la tutela e la conseguente trasmissione di un'identità storica di cui, in particolare, caselli ferroviari e ponti in muratura sono testimonianza.

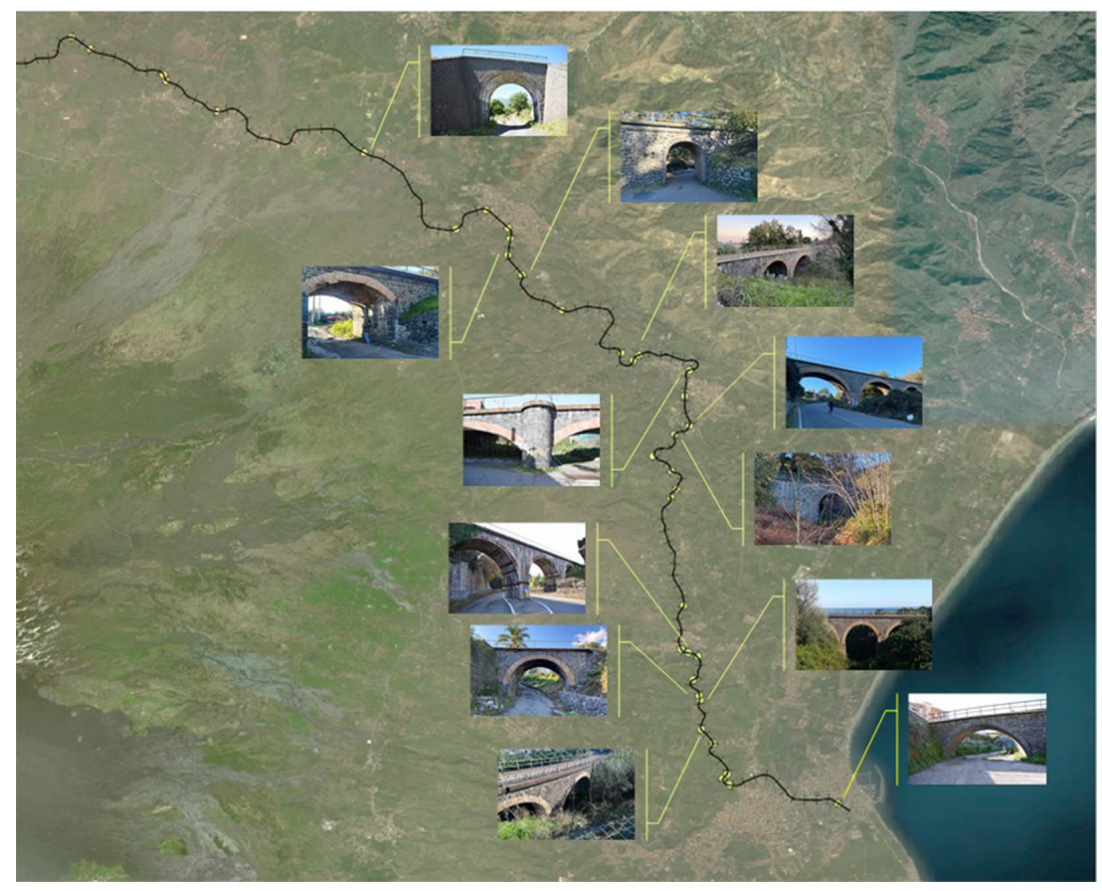




\section{Metodologia}

L'iter metodologico seguito per la sperimentazione condotta si è articolato in diverse fasi: fase I, ricerca documentale; fase 2, individuazione nel territorio e censimento; fase 3, rilievo digitale; fase 4, analisi.

\section{La ricerca documentale}

La ricerca e l'acquisizione di materiale documentale sulla Circumetnea si sono svolte in due fasi. È stata inizialmente consultata la documentazione presente all'Archivio di Stato di Catania, che custodisce 192 buste di documenti e progetti originali risalenti alla realizzazione della linea ferrata. In particolare, sono state acquisite digitalmente planimetrie, profili longitudinali e i progetti di ponti, gallerie, caselli, depositi e stazioni corredati dai relativi computi metrici. È stata consultata, altresì, parte della documentazione dell'epoca, che racconta il progetto e narra le vicende che ne hanno accompagnato la realizzazione. Le relazioni a corredo degli elaborati progettuali hanno permesso di indagare aspetti realizzativi e tecnologici inediti, sia per quanto riguarda le opere d'arte che gli edifici a supporto della linea ferrata. Successivamente sono state richieste le planimetrie catastali delle stazioni e dei caselli dismessi all'Agenzia delle Entrate. Ciò ha permesso di ottenere maggiori informazioni sulle configurazioni spaziali interne, data l'impossibilità di effettuare sopralluoghi all'interno di tali manufatti.

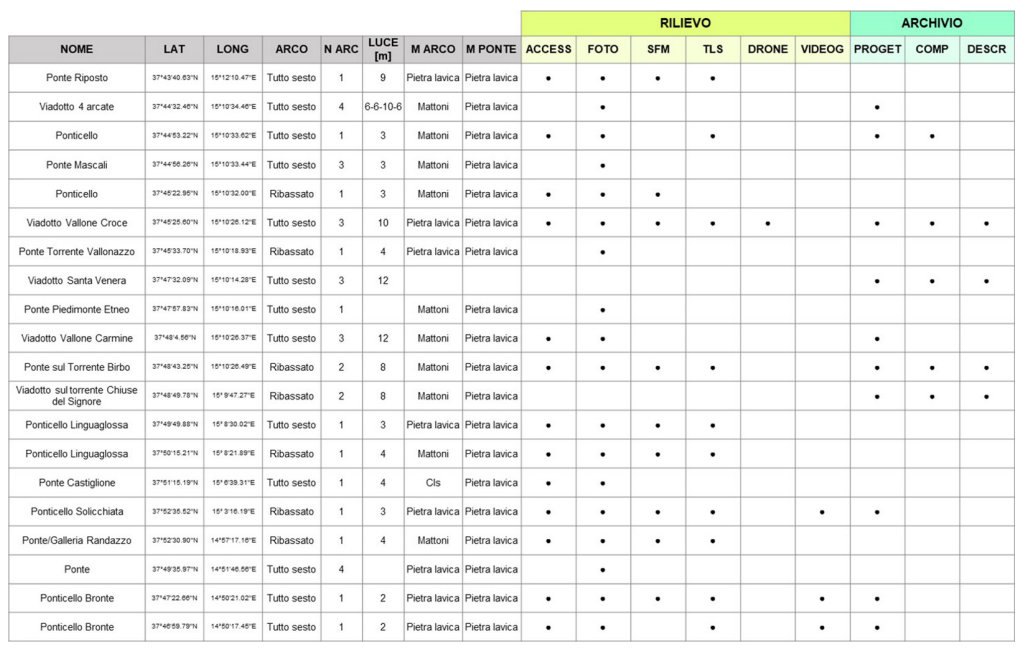

L'individuazione nel territorio, il censimento e la classificazione

Questa fase della ricerca si è incentrata sull'individuazione dei ponti e degli edifici a servizio della linea ferrata e sulla loro catalogazione con riferimento alle caratteristiche architettoniche e geometriche (fig. 2). Si è proceduto, innanzitutto, all'individuazione dei manufatti in esame con Google Earth, in modo da identificare rapidamente, quando possibile, le caratteristiche delle strutture individuate attraverso Google Street Maps, operando un armchair mapping preliminare [Inglese 2020]. Tali informazioni sono state successivamente integrate attraverso sopralluoghi sul posto.

Si è passati, quindi, all'importazione dei dati nella piattaforma QGIS. II percorso tracciato e i pin inseriti precedentemente in Google Earth, hanno mantenuto la 'vettorializzazione' (diventando rispettivamente linee e punti). Si è scelto di sovrapporre tali elementi a diverse webmap (rispettivamente Google Maps e Google Street Maps).

Sono state utilizzate, inoltre, la cartografia di base - IGM 25.000 e quella dei bacini idrografici principali e secondari. Nel caso dei ponti, dalla base cartografica si è passati all'arricchimento informativo, con l'obiettivo di produrre una griglia di attributi organizzata secondo categorie relative alla posizione (latitudine e longitudine), al numero di arcate, ai materiali, alla documentazione di archivio reperita e al tipo di rilievo eseguito (fig. 3). 


\section{II rilievo digitale}

Si è lavorato all'ottimizzazione della fase di acquisizione metrica e morfologica attraverso l'integrazione di diverse metodologie di rilevamento, quali l'utilizzo di laser scanner, fotogrammetria (da terra e da drone) e 'videogrammetria'. Sono state integrate tecniche di rilievo differenti a seconda delle condizioni ambientali e della tipologia di manufatto da rilevare. In questa fase è stato possibile acquisire digitalmente ponti urbani di luce modesta e ponti a una o più arcate facilmente raggiungibili e non ricadenti in terreni privati, i cui corsi d'acqua di riferimento non sono più in superficie. Sono state altresì rilevate, mediante laser scanner e fotogrammetria, una stazione, un casello e una garitta di guardia in disuso.

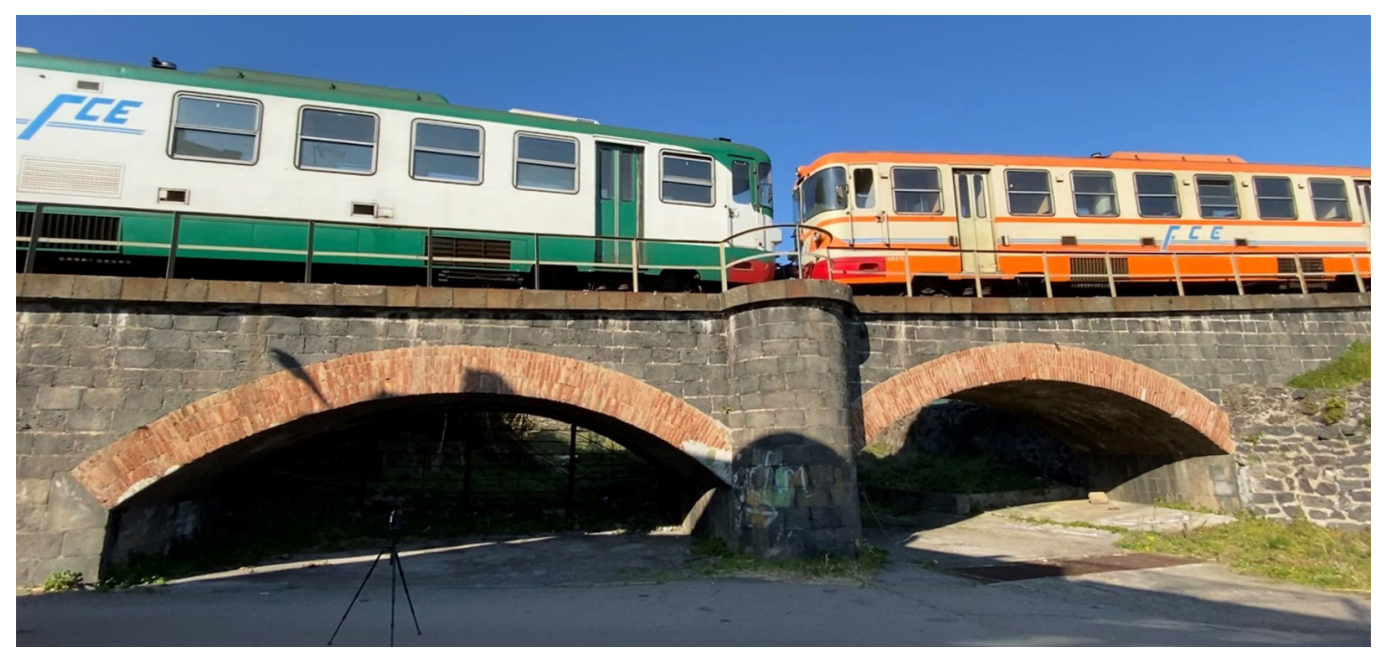

Analisi

Incrociando le informazioni ottenute attraverso la ricerca d'archivio, la cartografia storica e le webmaps, si è fatta corrispondere la documentazione storica ai manufatti in esame. In particolare, la sovrapposizione con l'IGM 25.000 e la cartografia dei bacini idrografici si è rivelata essenziale poiché alcuni manufatti sono identificati esclusivamente mediante il corso d'acqua, la contrada o la progressiva chilometrica (non più coerente a causa delle numerose varianti apportate alla linea).

La lettura dei progetti originali e il confronto con gli esiti del rilievo digitale hanno permesso di meglio approfondire le ragioni del progetto e le modifiche che nel tempo hanno interessato i manufatti, mettendo in evidenza il rapporto indissolubile che, soprattutto nel caso dei ponti, si crea con il contesto urbano e ambientale.

\section{Casi studio}

I casi studio illustrati, collocati lungo la tratta Riposto-Randazzo della linea, sono esemplificativi dell'impostazione metodologica illustrata e degli esiti applicativi attesi.

Ponti a due arcate sul torrente Birbo e sul torrente Chiuse del Signore II ponte a doppia campata (fig. 4), il cui progetto risale al I892, si trova ai margini del tessuto storico di Piedimonte Etneo, collocato al chilometro 106.00।,37 della progressiva chilometrica attuale. Curvando con un raggio di quasi $88 \mathrm{~m}$, il ponte attraversava il torrente Birbo, oggi interrato.

Ė composto da due volte a botte ad arco ribassato con una freccia pari a I,60 m; entrambe le campate presentano una luce netta di $8 \mathrm{~m}$ e sono profonde $3,70 \mathrm{~m}$.

Quale evidenza del precedente fluire del Birbo, sono presenti dei rostri a profilo semicircolare, che si concludono con un rifugio pedonale. Le pile, le spalle, i muri di ritorno e i timpani 
Fig. 5. II ponte sul torrente Chiuse del Signore (foto di E. Salamone, 2021). sono realizzati in muratura ordinaria in pietrame con paramento a corsi regolari e cantonali in pietra da taglio, lavorati a grana ordinaria. La volta è realizzata in laterizi.

Attualmente un solo ponte dalla configurazione analoga è stato individuato lungo la linea: si trova al chilometro 103.964,22, su un terreno privato e attraversava il torrente Chiuse del Signore (fig. 5). I due ponti, delle medesime dimensioni, differiscono per la diversa convessità della curvatura e per la muratura, in questo caso con paramento in pietrame disposto a mosaico.
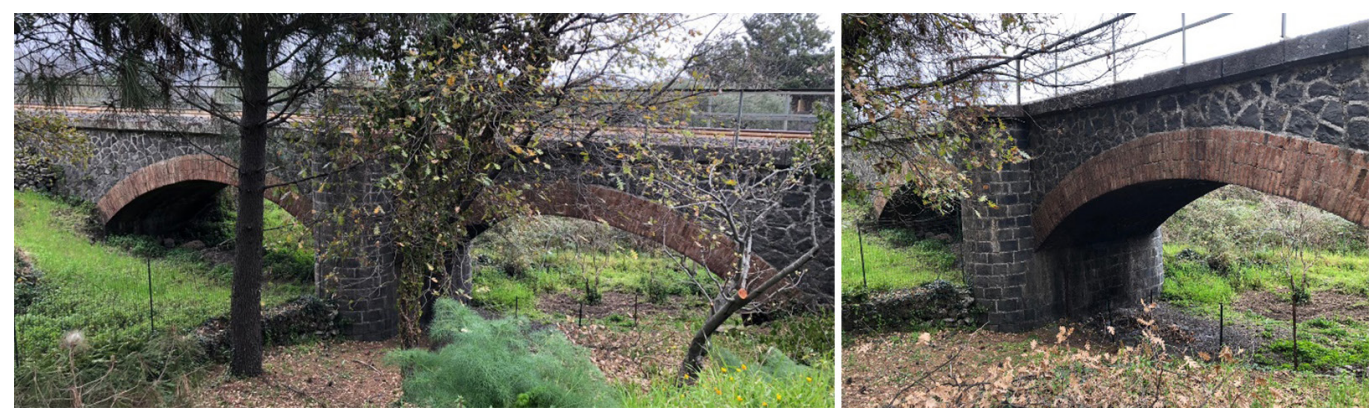

Ricerca storico-archivistica

Le variazioni progettuali inerenti alla tratta esaminata risultano evidenti dall'analisi della documentazione d'archivio, in particolare dal confronto tra i profili longitudinali del |886, del | 89 | e del 1892 (fig. 6).

Nel primo progetto del 1886 il Birbo consisteva in un ponte a singola arcata di 9 m di luce, ribassata con freccia pari a I,50 m. Le spalle, entrambe larghe 3, I54 m, erano caratterizzate dalla presenza di muri d'ala curvi per garantire un afflusso agevole dell'acqua (fig. 7 a).

II progetto del I89I, necessario a seguito delle varianti altimetriche operate, prevedeva un ponte a singola arcata ribassata di $8 \mathrm{~m}$ di luce, con freccia pari a 1,60 m (fig. 7b). Come riportato in una nota a corredo del progetto, la campata del ponte fu determinata prendendo a riferimento un ponte precedentemente realizzato che superava il medesimo torrente un centinaio di metri più a monte. Tale ponte, individuato grazie all'interpretazione dei documenti e a un'accurata osservazione della cartografia IGM 25.000 e dei bacini idrografici, è attualmente murato (fig. 8). Risale al 1892, invece, la configurazione attuale a due arcate (fig. 7c).

Analogamente, il ponte che attraversa il torrente Chiuse del Signore, la cui prima stesura progettuale risale al 1891, fu inizialmente concepito a travata metallica con arcata di scarico in muratura di 6 m. II progetto definitivo, coerente con lo stato di fatto del manufatto, risale, anche in questo caso al 1892.

\section{Rilievo digitale}

Considerando le modeste dimensioni delle arcate e la distanza modesta tra i piani di calpestio e di imposta (circa I metro), si è optato per un rilievo integrato utilizzando laser scanner e fotogrammetria.

È stato utilizzato il laser scanner BLK 360 della Leica Geosystem, con portata max. 60 m e velocità di scansione pari a 360.000 punti/sec. Al fine di colmare eventuali zone d'ombra e ottenere un modello numerico completo, sono stati previsti 14 punti stazione, di cui 4 sotto le arcate (una coppia per arcata), 6 sul fronte, 4 sul retro. Non è stato possibile, per motivi di sicurezza, effettuare scansioni in corrispondenza della via ferrata. L'esito di tali operazioni di acquisizione è un modello numerico di elevata risoluzione (570.193.486 punti) corredato da un efficace dato cromatico (fig. 9).

Ciononostante, si è ritenuto necessario integrare tale rilievo mediante fotogrammetria. È stato effettuato un dataset di 463 immagini ad alta risoluzione (4496×3000 pixels), realizzate con una Nikon D5300, distanza focale 18 mm, successivamente elaborate attraverso il software di fotogrammetria digitale Agisoft Metashape. La nuvola di punti ottenuta consta di 99.606.216 punti. Da questa è stato possibile estrapolare ortofoto da utilizzare per successive analisi ed elaborazioni bidimensionali. 
Fig. 6. I profili

longitudinali della linea in corrispondenza dei ponti sul torrente Birbo e sul torrente Chiuse del Signore. Documenti originali conservati presso l'Archivio di Stato del Comune di Catania fondo Circumetnea.
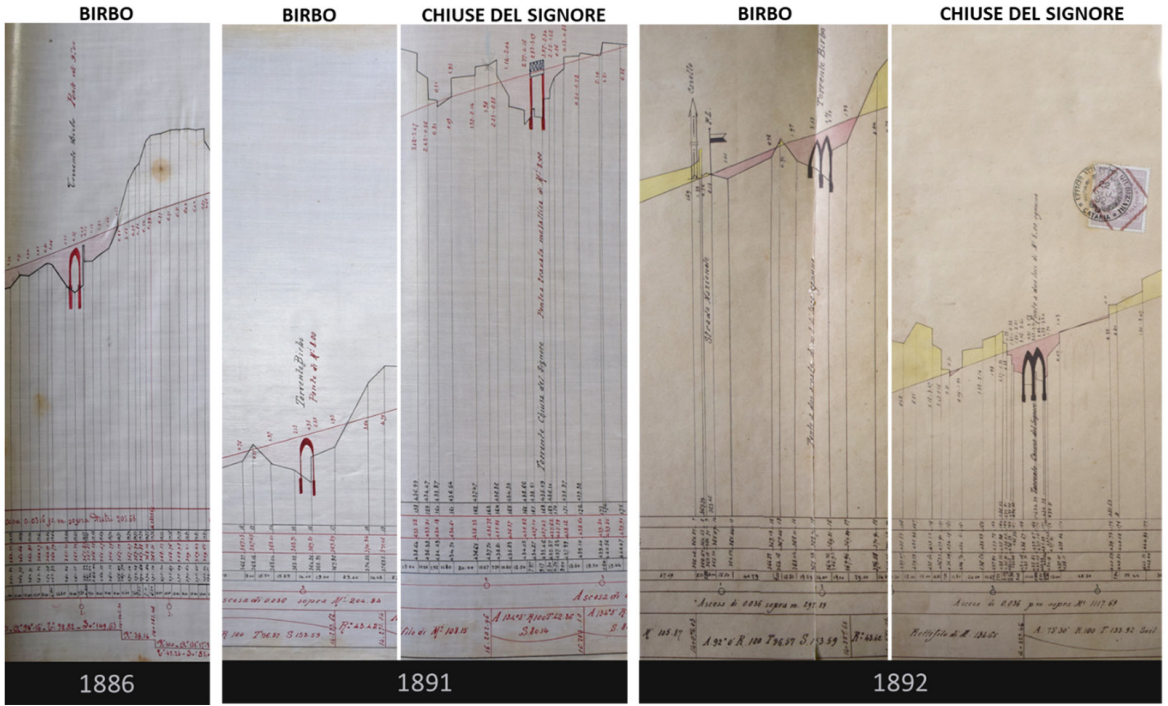

\section{Casello n. 92}

II casello 92 (fig. I0) è situato a un centinaio di metri rispetto al ponte sul torrente Birbo. II fabbricato, a doppia elevazione, è inutilizzato ma si presenta in buone condizioni e perfettamente integrato con il contesto urbano circostante. Le tecniche costruttive sono quelle della tradizione di fine Ottocento per gli edifici di tipo residenziale, caratterizzati da finiture modeste e dall'utilizzo dei materiali costruttivi dell'areale etneo.

\section{Ricerca storico-archivistica}

Dal punto di vista compositivo, il casello in esame è composto da un'unità abitativa "tipo" (due vani distribuiti in altezza collegati da una scala) cui sono stati giustapposti altri volumi, assecondando presumibilmente le esigenze del casellante. II progetto di tale "cellula", denominatore comune ad altri caselli lungo la tratta, è stato reperito presso l'Archivio di Stato (fig. I la).
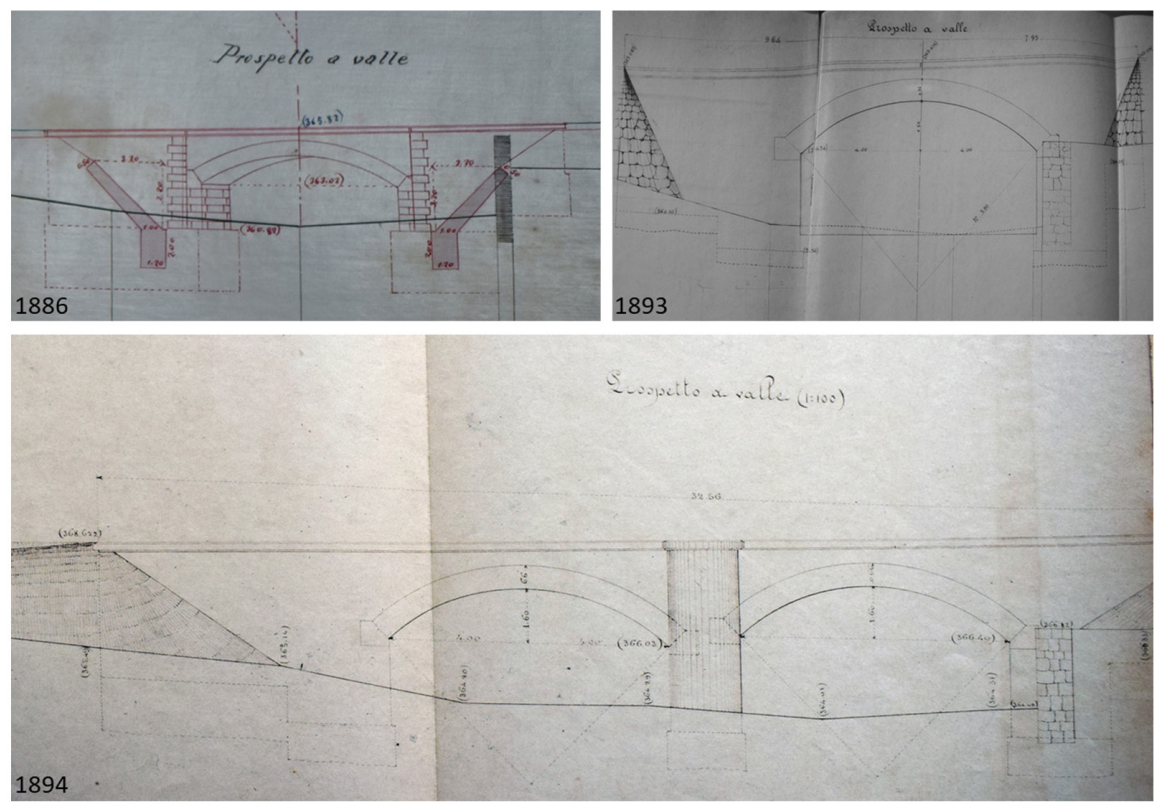
Attraverso l'analisi delle planimetrie catastali si è potuta appurare, invece, la differente distribuzione interna, che presenta, oltre al modulo già descritto, una cucina con bagno, due ulteriori vani, di cui uno accessibile unicamente dall'esterno e un locale di sgombero, oggi non più esistente (fig. l l b).

\section{Rilievo digitale}

Anche in questo caso si è scelto di rilevare l'involucro dell'edificio utilizzando il BLK 360, data la modesta altezza e la geometria essenziale del manufatto. Sono state effettuate quattro scansioni, per un totale di I33.549.7 I I punti, comprensivi di parte consistente del contesto (fig. 12).

Fig. 8. Localizzazione sulligm l.25.000 del Casello 93 (A) del ponte sul torrente Birbo (B) del ponte sul torrente Chiuse del Signore. $C$, nella foto in basso a sinistra, è il ponte preso a riferimento per la progettazione della campata del ponte sul torrente Birbo.

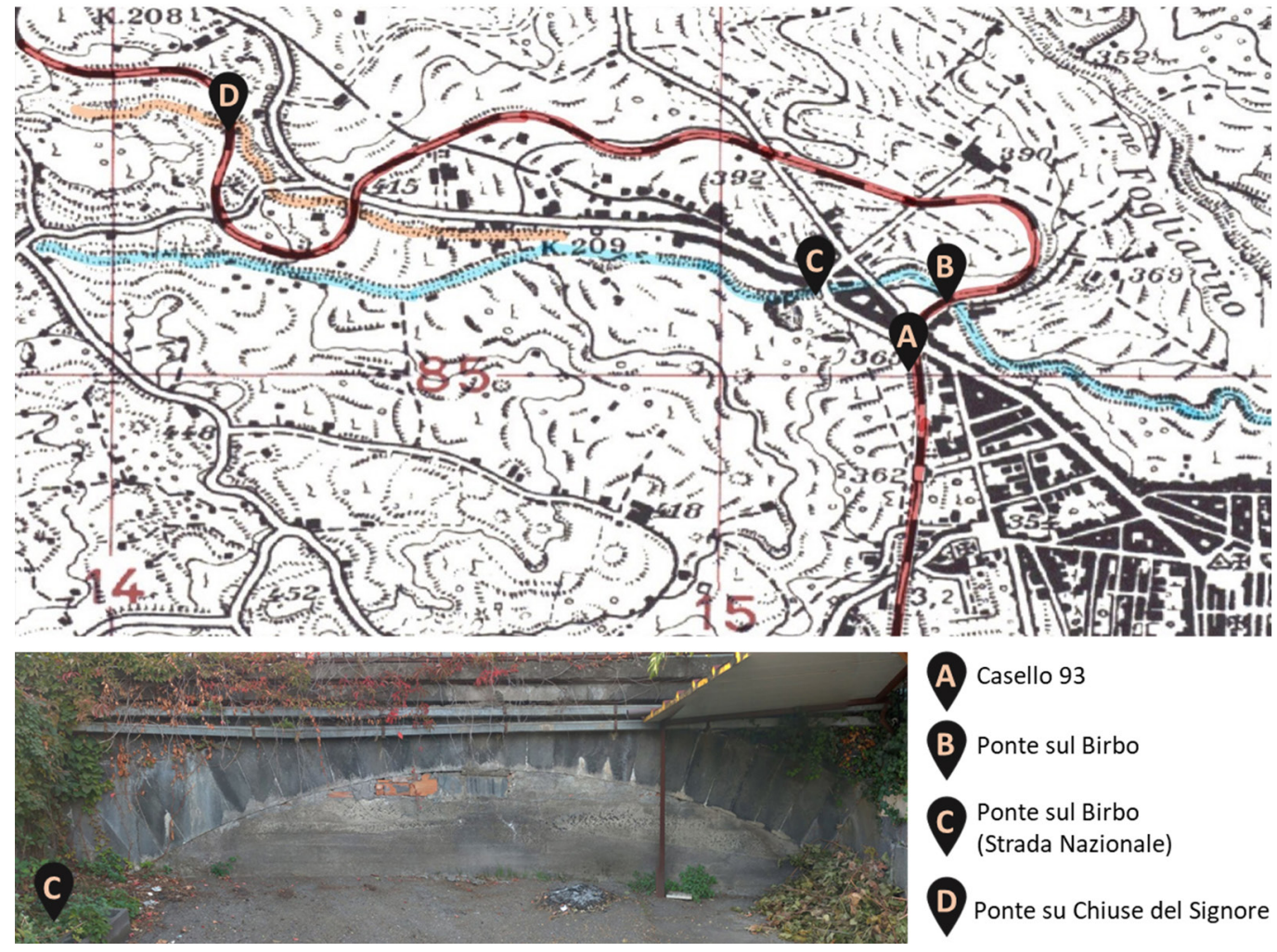

\section{Conclusioni e sviluppi futuri}

La ricerca condotta ha restituito il ricco patrimonio, costituito da opere di ingegneria e di architettura a corredo della linea ferrata della Ferrovia Circumetnea, testimonianza di una cultura del costruire improntata ai principi di sostenibilità e rispetto del territorio. La lettura a ritroso dell'iter progettuale a confronto con lo stato di fatto consente di avanzare ipotesi sugli assetti orografici e ambientali originari, oggi stravolti da un uso intensivo del territorio, fornendo chiavi di lettura inedite sulla trasformazione di questi luoghi nel tempo.

II censimento e la classificazione delle tipologie di ponti, caselli e stazioni lungo la tratta, unitamente alle attività di rilievo digitale, forniscono una base conoscitiva preziosa ed esaustiva, essenziale in vista di interventi di recupero e conservazione, del monitoraggio o della valorizzazione e riqualificazione del territorio o dell'ambiente urbano di sono parte. La ricerca proseguirà attraverso la creazione di modelli informativi contestualizzati nel territorio al fine di mettere in relazione i dati acquisiti secondo una prospettiva olistica, che tenga conto di tutte le valenze che caratterizzano questi episodi che punteggiano il paesaggio pedemontano etneo. 
Fig. 9. In alto, progetto di ripresa del rilievo tramite laser scanner, destra e in basto viste prospettiche del modello numerico finale.

Fig. I0. II casello 92 fotografato da un punto di ripresa in prossimità del ponte sul torrente Birbo.

Fig. I I. a) A sinistra, il progetto del Casello semplice di guardia, individuata quale unità abitativa "tipo". b) A destra, a planimetria

catastale del casello in esame, con evidenziata la cellula abitativa.

Fig. 12. La nuvola di punt del casello 92 ottenut mediante rilievo laser scanner.
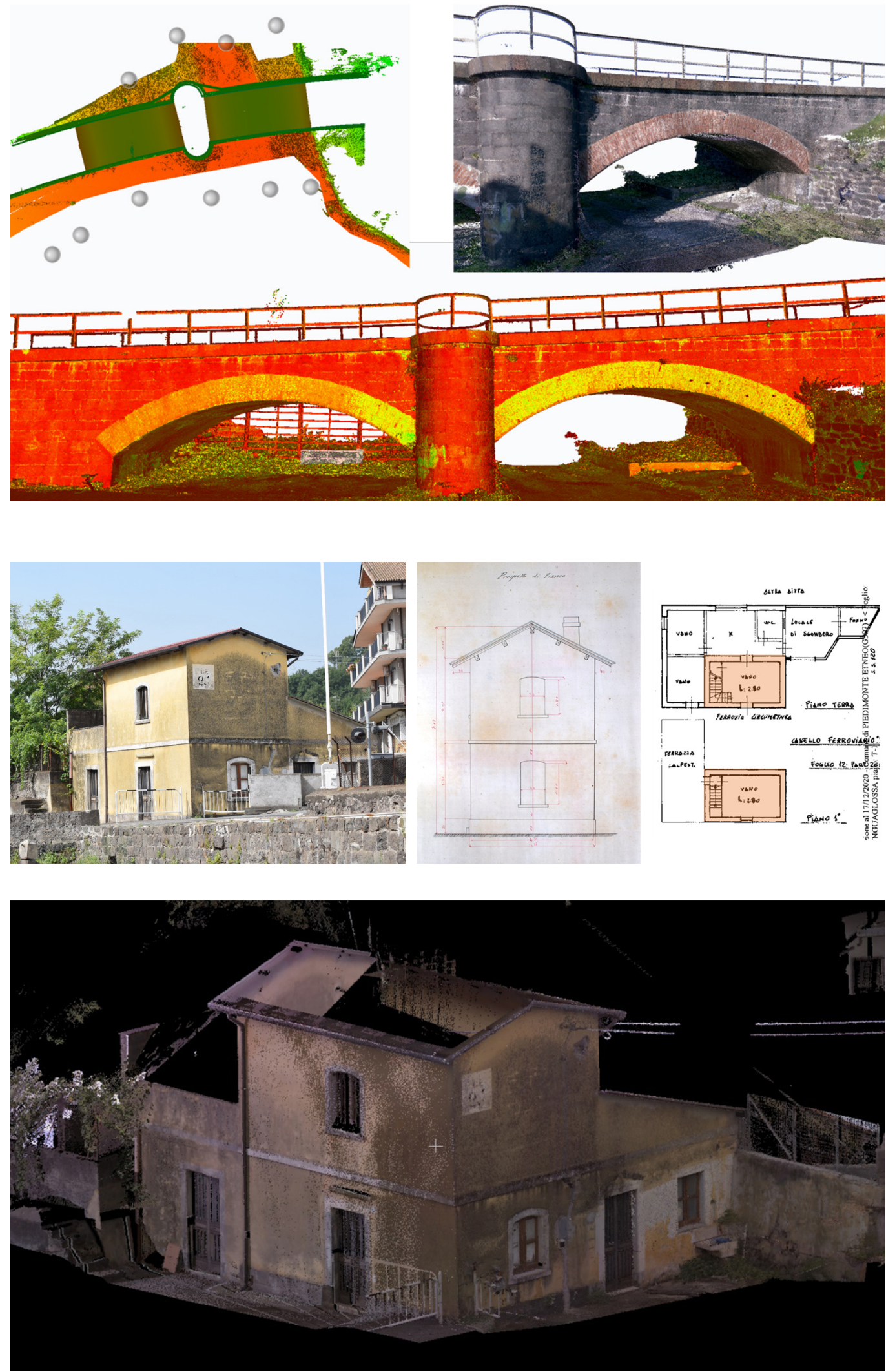


\section{Crediti}

Entrambe le autrici hanno dato contributi sostanziali al progetto. Raissa Garozzo si è occupata della concettualizzazione, dello sviluppo della metodologia, delle analisi e del trattamento dei dati; Cettina Santagati si è occupata della concettualizzazione, dello sviluppo della metodologia, della supervisione del progetto. L'attribuzione dei paragrafi è da considerarsi la seguente: I,2,3 e 4 Raissa Garozzo, I e 5 Cettina Santagati.

\section{Riferimenti bibliografici}

Battino S., Donato C., Mele G. (20/8). Turismo sostenibile e culturale nelle aree interne del Nord Sardegna:Viaggi sul "trenino dei due mari". Trieste: EUT.

Bonanno L. (1999). Architetture del paesaggio: Ponti di Sicilia. Medina.

Cantalupi A. ( 1884$)$. La costruzione dei ponti e dei viadotti: trattato di architettura pratica. Milano: Vallardi.

Cresta A. (2019). Mobilità sostenibile e valorizzazione turistica delle aree interne: I treni storici tra identità e paesaggio <https://doi. org/ 0.13 | 37/2282-572X/3 |729> (consultato il 3 Febario 2021).

Curioni G. (1870). L'arte di fabbricare. Costruzioni civili, stradali e idrauliche. Torino: Augusto Federico Negro.

Dal Sasso P., Ottolino M.A. (2012). Greenway in Italy: Examples of projects and implementation. In Journal of Agricultural Engineering. n. 42 (I), 29. <https://doi.org/ I0.408 I/jae.20 I I.39> (consultato il 3 Febbraio 202 I).

Damiata D. (20।4). Digital Stereotomics: L'apparecchiatura elicoidale dei ponti obliqui. "Ponte a Grisignano di Zocco". Padova: Università degli Studi di Padova.

Fadda S. (1915). Costruzione ed esercizio delle strade ferrate e delle tramvie. Album di costruzioni ferroviarie. Torino: UTET.

Inglese C., Paris L. (2020). Arte e tecnica dei ponti romani in pietra. Roma: Sapienza Università Editrice.

León-Robles C., Reinoso-Gordo J., González-Quiñones J. (2019). Heritage Building Information Modeling (H-BIM) Applied to A Stone Bridge. In ISPRS International Journal of Geo-Information. n. 8(3), I 2 I <https://doi.org/ I 0.3390/ijgi8030 I 2 I > (consultato il 3 Febbario 2021)

Manganaro M. (20I I). Ponti e paesaggio rurale in Sicilia: Disegni e note/Bridges and the countryside in Sicily: Drawings and notes. In Disegnare. Idee Immagini n. 42, pp. 12-21.

Moschella A., Auricchiella A. (2017). Recupero e rifunzionalizzazione degli edifici ferroviari dismessi: Un'occasione per la ri-generazione del Parco Lineare tra Caltagirone e San Michele di Ganzaria. In Palma Crespo M., Gutiérrez Carrillo L., García Quesada R. (eds). ReUSO, Granada 20 17: Sobre Una Arquitectura Hecha de Tiempo. Granada : EUG, vol.2 pp. 319-326.

Oppido S. (2020). Linee ferroviarie e valorizzazione del paesaggio. Orientamenti e sperimentazioni. In Diano D., Pinto M. R., (a cura di.) Reti ferroviarie e valorizzazione dei territori. Recupero, manutenzione e innovazione delle stazioni. Napoli: Scuola di Pitagora pp. $173-187$.

Pavletits P. (202I). The Role and Possibilities of Hungarian Narrow-Gauge Railways in Tourism. In Kaposi Z., Rab V., Studies on Economic and Social History from Southern Transdanubia. vol. I, pp. I 32- I39 < https://doi.org/I 0. I 5 I 70/SESHST-0 I-I 5 > (consultato il 3 Febbraio 202I)

Petino G.,Wilson J., Knudsen D. C. (2018). Slow tourism in the ETNA Meso Region: Discovering the rural space with the Circumetnea railway. https://doi.org/I 0.I 3 I 40/RG.2.2.I4288.56327> (consultato il 3 Febbraio 202 I).

Sánchez-Rodríguez A. et al. (2018). Detection of structural faults in piers of masonry arch bridges through automated processing of laser scanning data. In Structural Control and Health Monitoring. n. 25(3). <https://doi.org/l 0. I 002/stc.2 I 26 > (consultato il 3 Febbraio 2021).

Savini F. et al. (202I). Applications of Stratigraphic Analysis to Enhance the Inspection and Structural Characterization of Historic Bridges. In Infrastructures n. 6 (I) <https://doi.org/ I0.3390/infrastructures60 I 0007> (consultato il 3 Febbraio 202 I)

Tomasetti G. (2020). Un corridoio verde tra Langhe, Roero e Monferrato. La svolta "green" della linea ferroviaria dismessa tra Alba e Castagnole delle Lanze e il recupero dei fabbricati in disuso [PhD Thesis]. Università degli Studi di Genova.

Vaschetto D. (2017). Le più belle ferrovie secondarie d'Italia: /l Centro-Nord. Torino: Edizioni del Capricorno.

\section{Autori}

Raissa Garozzo, Università degli Studi di Catania raissa.garozzo@unict.it

Cettina Santagati, Università degli Studi di Catania, cettina.santagati@unict.it

Per citare questo capitolo: Garozzo Raissa, Santagati Cettina (202I). Nuove prospettive sulla ferrovia Circumetnea: un viaggio tra archivi e rappresentazione digitale/Novel perspectives on the Circumetnea railway: a journey across archives and digital representation. In Arena A., Arena M. Mediati D. Raffa P. (a cura di). Connettere. Un disegno per annodare e tessere Linguaggi Distanze Tecnologie. Atti del $42^{\circ}$ Convegno Internazionale de Docenti delle Discipline della Rappresentazione/Connecting Drawing for weaving relationship. Languages Distances Technologies. Proceedings of the $42^{\natural}$ International Conference of Representation Disciplines Teachers. Milano: FrancoAngeli, pp. 1649 - 1668 


\title{
Novel Perspectives on the Circumetnea Railway: a Journey Across Archives and Digital Representation
}

\author{
Raissa Garozzo \\ Cettina Santagati
}

\section{Abstract}

The railway networks, which connect people and territories, are the result of the technological innovations of the late nineteenth century. As a way of transport that gives back to the traveller the opportunity to cross space and time to reach a destination, they mark the Italian landscape with their route, merging in the environmental context. The engineering works of art (bridges and tunnels) and the service buildings (stations, signalman's houses, guardhouses, and warehouses) constitute points of reference in the collective imaginary. The study investigates, through the instruments of architectural survey and the critical investigation, the route, and the engineering works of the Circumetnea railway. Indeed, it is the only narrow-gauge railway still in operation in Sicily that connects Catania to Riposto crossing several towns in the Etna foothills. Built at the end of the 19th century to improve the economy of the agricultural and manufacturing activities in the Etnean territory, it is a proof of theoretical knowledge and construction skills of the past with a skilful and sustainable use of traditional local materials. The proposed study aims at analysing the Circumetnea railway through the census, the classification, and the documentation of its works of art in a perspective of knowledge, preservation, and enhancement.

Keywords

masonry bridges; signalman's houses; industrial archaeology; archival research; digital survey.

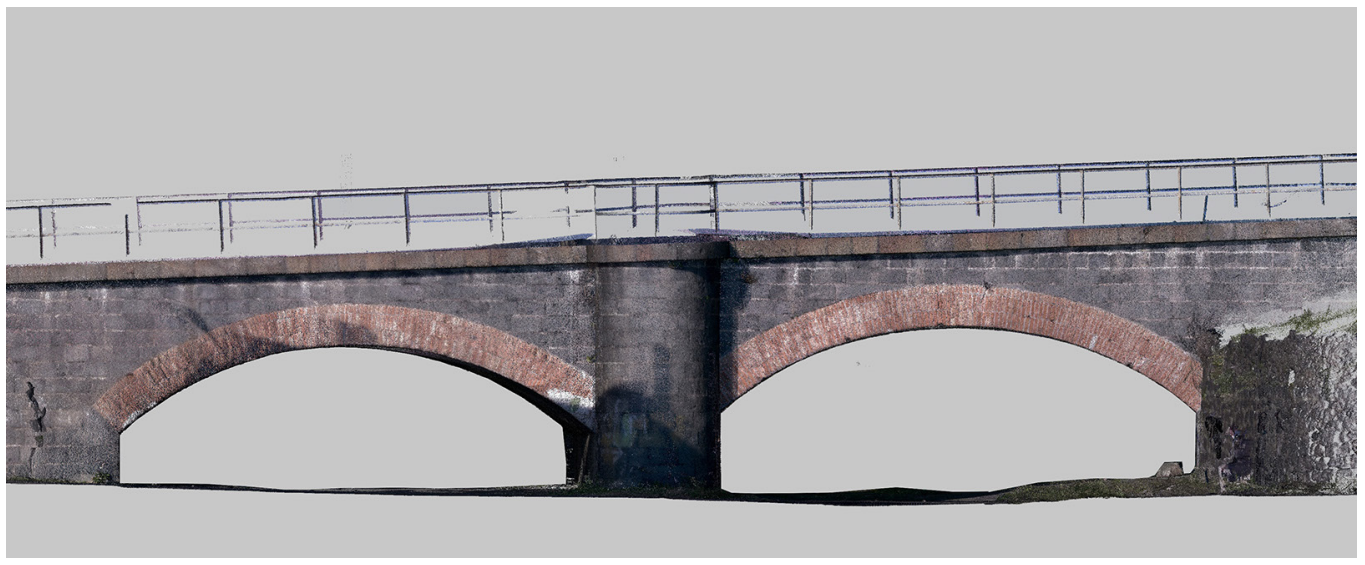




\section{Introduction}

Sicilian railway network is a key heritage consisting of continuous routes connecting towns and villages, dotted with civil engineering works (such as bridges and tunnels) and buildings (such as stations, signalman's houses, guardhouses, and warehouses). Despite this heritage is evidence of an important chapter in the history of post-industrial Sicily, nowadays a part of it is abandoned. Indeed, very few remains of the extensive Sicilian railway network, made up of standard and narrow-gauge lines.

The impetus for the creation of this infrastructure network can be identified in the importance of the island's sulphur basins and in the increasing requests coming from the agricultural, industrial, and manufacturing sectors at the end of the 19th century.

The development of the automotive industry and the increase in the individual motorisation rate led to the abandonment and consequent deterioration of the narrow-gauge railway lines in Sicily, except for the Circumetnea, the only railway of this type still in service. Built between 1889 and 1895 to support the economic dynamics of the agricultural and manufacturing sectors in the Etna area, the Circumetnea connects Catania to Riposto, almost encircling the Mount Etna Volcano and passing through several towns in the foothills surrounding Etna. Today it is one of the most evocative ways to explore the Etnean territory, with its slow-speed pace through urban centres, villages, vineyards, and lava landscapes (fig. I).

Except for the section from Catania to Biancavilla, which has been significantly modified over time, the Circumetnea still preserves its original design features. The bridges, tunnels, and buildings along its route, which are evidence of the theoretical knowledge and construction skills of the past, have over time become part of the landscape in which they are built; the use of traditional local materials, such as lava stone, has also made them distinctive features of the Etna railway line.

The undoubted identity value of these artefacts, icons of the landscape and points of reference in the collective imagination, emerges in their distinctive features and in the use of local materials, which make them a unique feature in Sicily.

Despite this, it is a heritage at risk: bridges and tunnels are threatened to be demolished due to the changing needs of the road network and the inevitable urban expansion; the related architectures, no longer in use, are subject to natural obsolescence due to neglect and lack of maintenance.

Given these premises, the proposed study aims to investigate the Circumetnea railway through its related works, in a perspective of knowledge, conservation and enhancement.

To do this, archive documentation, historical cartography and digital surveys were collected, analysed, and compared, reconnecting the past and present of the Circumetnea.

The study of the geometric configurations, construction techniques and reasons for the project, together with the use of the investigative tools of digital representation and surveying, is certainly the starting point for protecting a testimonial part of Sicily's industrial archaeological heritage that is now arousing renewed interest in the scientific community.

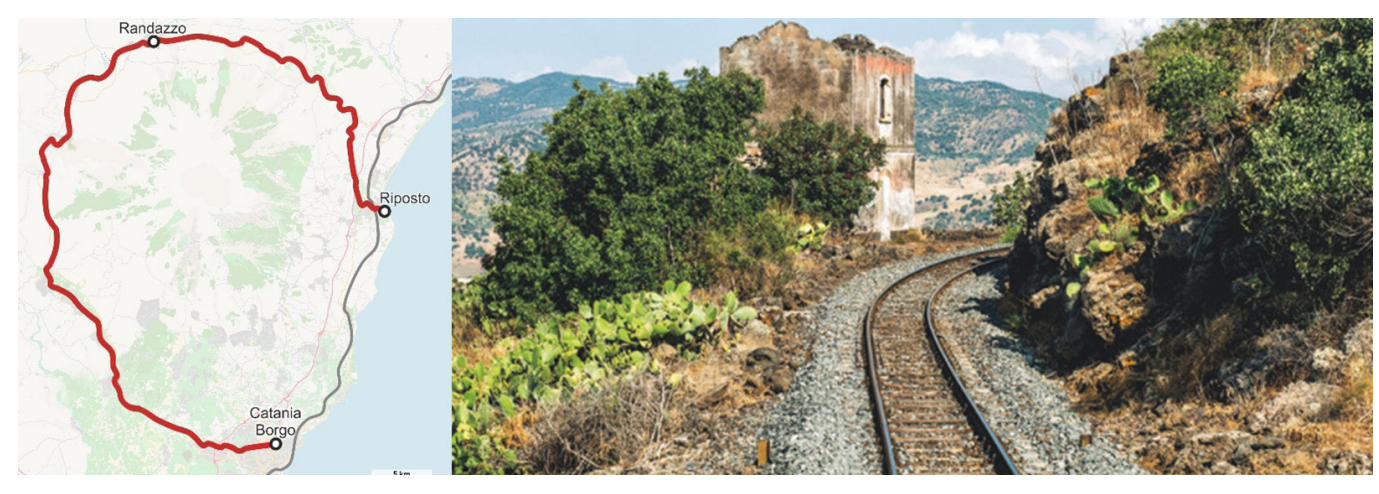




\section{The railway landscape and its infrastructure}

Recovery of disused railway routes through the creation of linear parks and nature trails [Cresta 2019; Dal Sasso 2012; Oppido 2020] or enhancement of slow-moving lines built in contexts with an articulated orography [Battino 2018; Pavletits 2021; Petino 2018] are interventions on historical railway contexts that do not require new infrastructures, but can use the vast existing heritage, with a view to reuse and sustainability.

The railway signalman's houses, available to railway workers and their families to allow uninterrupted control of the line, are the tangible signs of a recently concluded past [Vaschetto $2017]$. Their recovery which starts from the knowledge and survey of the artefacts can create a virtuous system of relationships between context and pre-existing heritage [Moschella 2017; Tomasetti 2020].

Conservation and design interventions require a multidisciplinary approach; a process of knowledge by progressive levels of investigation is, therefore, fundamental. The architecture of masonry bridges is a significant factor in the interpretation and representation of the territory, especially from a perspective point of view [Bonanno 1999]. Even though life drawing is a privileged tool in this sense [Manganaro $20 \mathrm{ll}$ ], in the analysis of the bridge-territory system and in the digital reproduction of the artefact, the point cloud has a vast potential and is suitable for multiple fields of application.

In Damiata [Damiata 2014] the cloud from photogrammetry is used for the stereotomic analysis of a diagonal bridge; in León-Robles [León-Robles 2019] historical-archival research and digital survey are used as database for the creation of Historical Bridge Information Models (HBrlM). Sánchez-Rodríguez [Sánchez-Rodríguez 2018] introduces, instead, a new methodology for the automated processing of large point clouds for the diagnosis of structural pathologies in masonry bridges. In Savini [Savini 202 I] the importance of an integrated approach for the knowledge of the technological and structural characteristics of masonry bridges is pointed out by applying the archaeological stratigraphic method and a 3D data management starting from the digital survey.

It is evident how the historical-critical analysis of the original project together with the geometric-structural survey of the railway works of art is essential for the protection and transmission of a historical identity that railway signalman's houses and masonry bridges testify to.

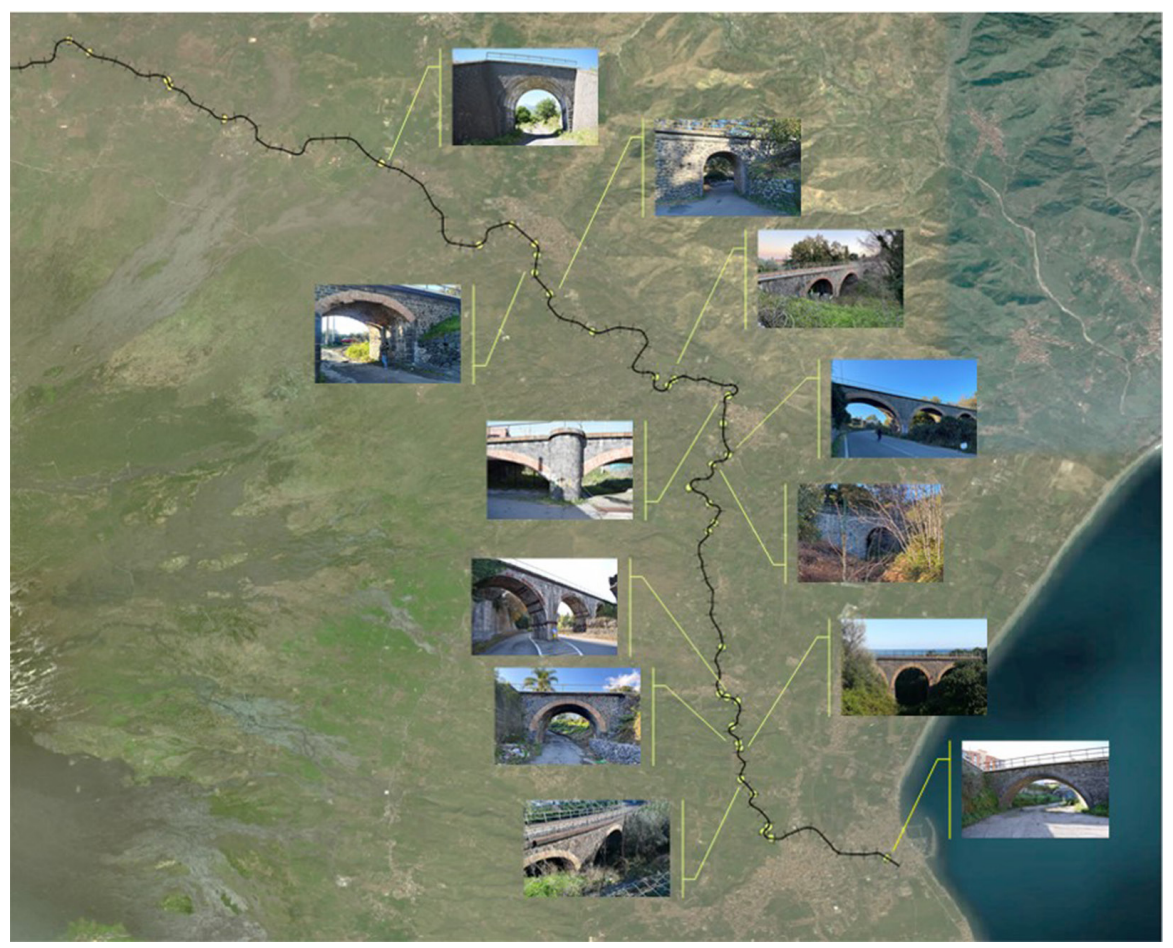




\section{Methodology}

The methodology followed is divided into several phases: phase I, documentary research; phase 2, identification in the territory and census; phase 3, digital survey; phase 4 analysis.

\section{Documentary research}

The research and collection of documentary material on the Circumetnea was carried out in two stages. Firstly, the documentation in the State Archive of Catania was consulted. It contains 192 folders of original documents and plans dating back to the construction of the railway line.

Plans, longitudinal profiles and projects for bridges, tunnels, signalman's houses, deposits, and stations were digitally acquired, together with the corresponding metric computations. Part of the historical documentation describing the project and the events that accompanied the construction was also consulted. The reports that supported the design drawings made it possible to investigate previously unexplored construction and technological aspects, both on the works of art and the buildings supporting the railway line.

Subsequently, cadastral plans of the disused stations and signalman's house were requested from the Italian Revenue Agency. This made it possible to obtain more information on the internal spatial configurations, given the difficulty of carrying out on-site inspections inside these buildings.

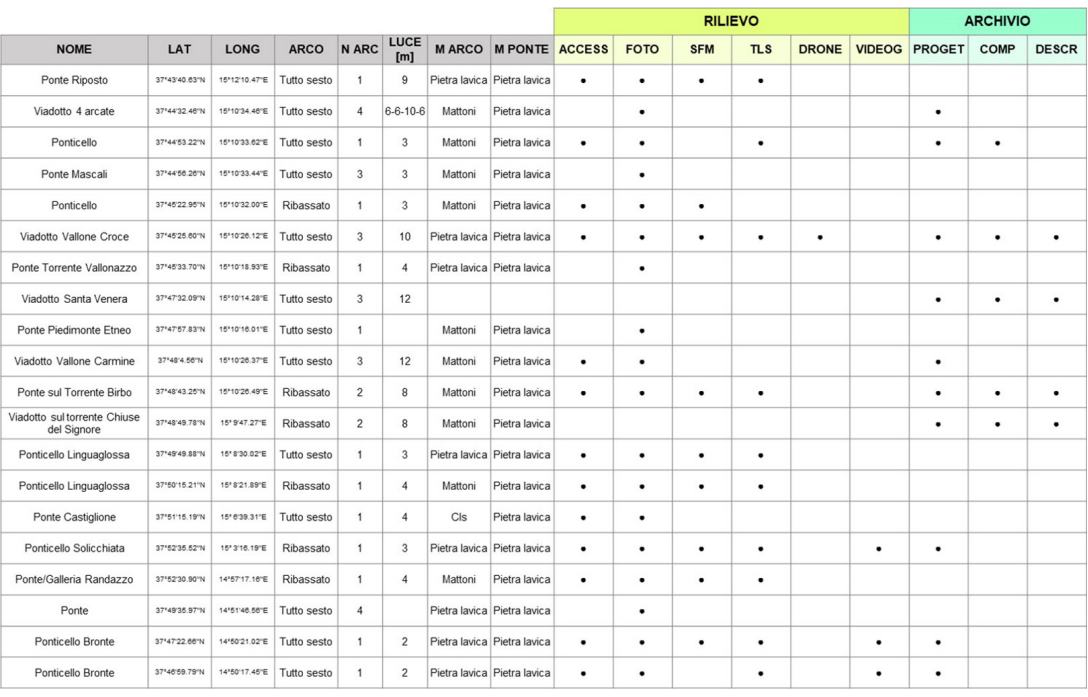

Identification in the territory and census

This phase of the research focused on the identification of the bridges and buildings serving the railway line and their cataloguing with reference to the architectural and geometric characteristics (fig. 2). First, the artefacts were pinpointed with Google Earth, to quickly identify, when possible, the characteristics of the structures detected through Google Street Maps, operating a preliminary armchair mapping [Inglese 2020]. This information was subsequently integrated through on-site inspections.

The data were then imported into the QGIS platform. The traced route and the pins previously inserted in Google Earth maintained their vectorization (becoming lines or points). It was decided to superimpose these elements on different web maps (Google Maps and Google Street Maps respectively).

In addition, the base cartography - IGM 25,000 and the cartography of the main and secondary catchment areas were used. Regarding the bridges, the cartographic base was enriched with information, with the aim of producing a grid of attributes organised according to categories relating to position (latitude and longitude), number of arches, materials, archival documentation, and type of survey carried out (fig. 3). 


\section{Digital survey}

The optimisation of the metric and morphological acquisition phase was carried out through the integration of different surveying methods, such as the use of laser scanners, photogrammetry (terrestrial and drone) and 'videogrammetry'. Different survey techniques were integrated according to the environmental conditions and the type of artefact to be surveyed. In this phase, it was possible to digitally acquire urban bridges of modest span and bridges with one or more arches that are easily accessible and do not belong to a private property, whose reference watercourses are no longer existing. A station, a signalman's house and a disused guard house were also surveyed using laser scanning and photogrammetry.

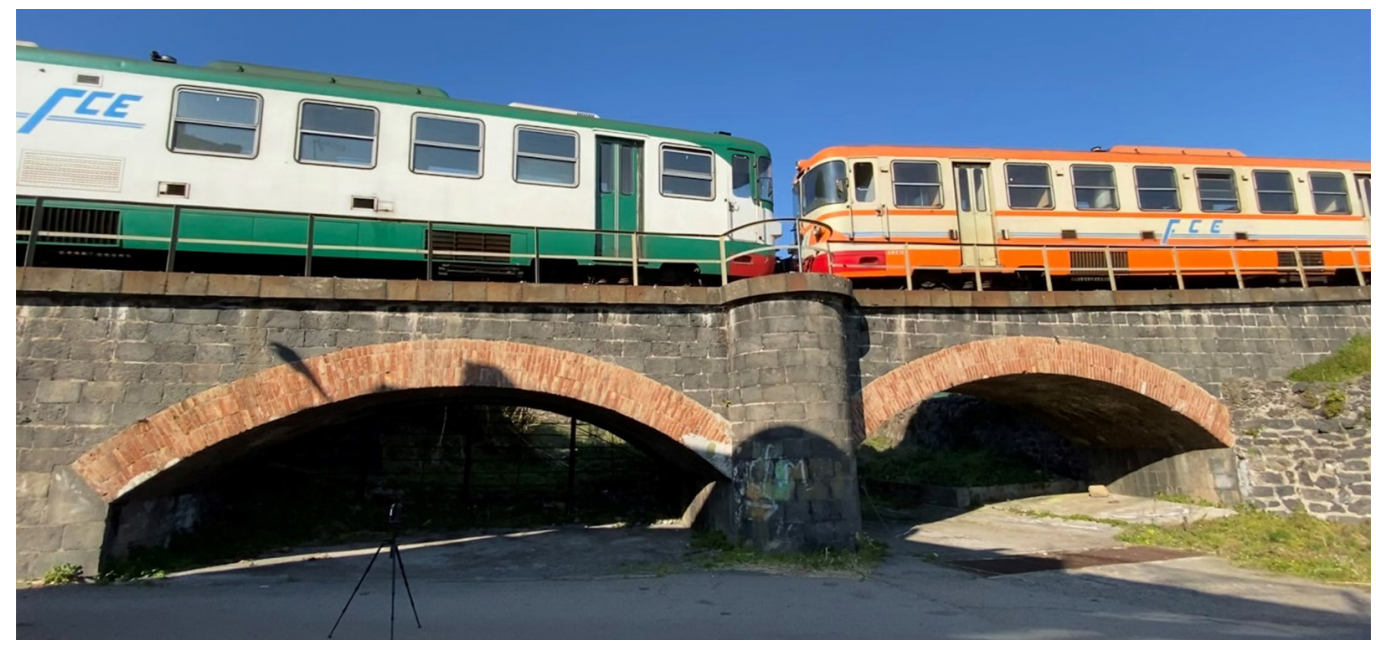

Analysis

The historical documentation was matched to the artefacts under examination through the combination of the information obtained with archival research, historical cartography, and web maps. Especially, the overlapping with the IGM 25.000 and the cartography of the hydrographic basins proved to be essential since some structures are identified exclusively by the watercourse, the district or the kilometric progressive (no longer consistent due to the numerous variations made to the line).

The original plans and the comparison with the results of the digital survey made it possible to better understand the reasons for the project and the modifications that affected the structures over time, highlighting the interconnection that, especially in the case of bridges, is established with the urban and environmental context.

\section{Case studies}

The case studies presented, located along the Riposto-Randazzo section of the line, are illustrative of the methodological approach illustrated and the expected application results.

The Double-span bridges crossing the Birbo and Chiuse del Signore torrents The double-span bridge (fig. 4), designed in 1892 , is located on the edge of the historical city centre of Piedimonte Etneo, at kilometre 106001,37 along the current route. Curving with a radius of almost $88 \mathrm{~m}$, the bridge crossed the Birbo torrent [ $\mathrm{l}$, now buried.

It consists of two barrel-vaults with a lowered arch and a span of $1.60 \mathrm{~m}$; both spans have a net span of $8 \mathrm{~m}$ and are $3.70 \mathrm{~m}$ deep.

As evidence of the previous flow of the Birbo, there are semi-circular rostrums, which end with a pedestrian refuge. The piers, abutments, return walls and gables are made of ordinary 
lava stone masonry with a regular course face and cornerstones of ordinary-grained cut lava stone. The vault is made of bricks.

Currently only one bridge of similar configuration has been identified along the line: it is located at km 103,964.22, on private land and crossed the Chiuse del Signore stream (fig. 5). The two bridges have the same dimensions but are different for the convexity of the curvature and for the masonry typology, in this case with a stone face arranged in mosaic.

Fig. 5. The bridge over the Chiuse del Signore river (photo by E. Salamone 202I).
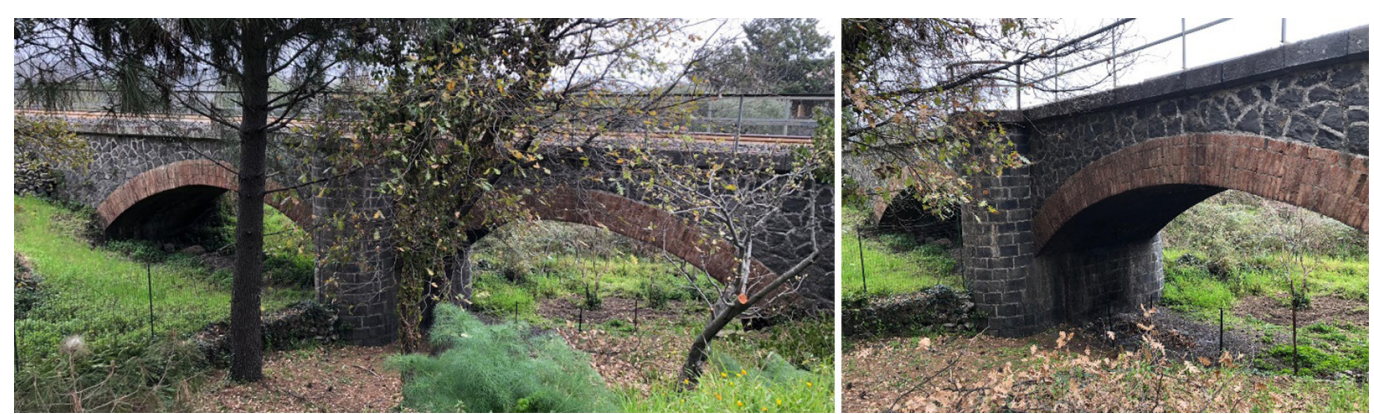

\section{Historical and archival research}

The design variations on the railway section under consideration are noticeable from the archival documentation and the comparison of longitudinal profiles [2] dated I886, I89 | and 1892 (fig. 6).

In the first project of 1886 , the Birbo consisted of a single arch bridge with a span of $9 \mathrm{~m}$ and a lowered span of $1.50 \mathrm{~m}$. The abutments, both $3.154 \mathrm{~m}$ wide, were characterised by curved wing walls to ensure a smooth flow of water (fig. 7a).

The I89| modifications, due to alterations in height, provided for a single lowered arch bridge with a span of $8 \mathrm{~m}$ and an arrow of $1.60 \mathrm{~m}$ (fig.7b). As reported in a note accompanying the project, the span of the bridge was determined by taking as a reference another bridge previously built, which crossed the same stream about one hundred metres upstream. This bridge, identified through the interpretation of documents and a careful observation of the IGM 25,000 cartography and the hydrographic basins, is currently walled up (fig.8). The current two-arch configuration dates to I 892 (fig.7c).

Similarly, the bridge crossing the Chiuse del Signore stream, which was first designed in I89 |, was initially conceived as a metal truss with a $6 \mathrm{~m}$ long masonry arch. The final drawing also dates to 1892 and is in line with the current state of the artefact.

\section{Digital survey}

Considering the modest size of the arches and the small height of the imposts (about I metre), an integrated survey using laser scanning and photogrammetry was chosen.

The Leica Geosystem BLK 360 laser scanner was used, with a maximum range of $60 \mathrm{~m}$ and a scanning speed of 360,000 points/sec. To compensate for any shady areas and to obtain a complete numerical model, 14 station points were set up, including 4 under the vaults (one pair per arch), 6 on the front and 4 on the back. The result of these surveying operations is a high-resolution numerical model (570,193,486 points) (fig. 9).

Nevertheless, it was considered necessary to integrate this survey with photogrammetry. A dataset of 463 high-resolution images (4496×3000 pixels) was collected with a Nikon D5300, focal length $18 \mathrm{~mm}$. These images were processed using the Agisoft Metashape digital photogrammetry software. The point cloud obtained consists of 99,606,216 points. Orthophotos were extrapolated from the cloud for subsequent analysis and two-dimensional metric drawings. 
Fig. 6. Longitudinal profiles of the line in correspondence with the bridges over the Birbo and Chiuse del Signore rivers. Original documents held in the State Archives of Catania, Circumetneo fund.
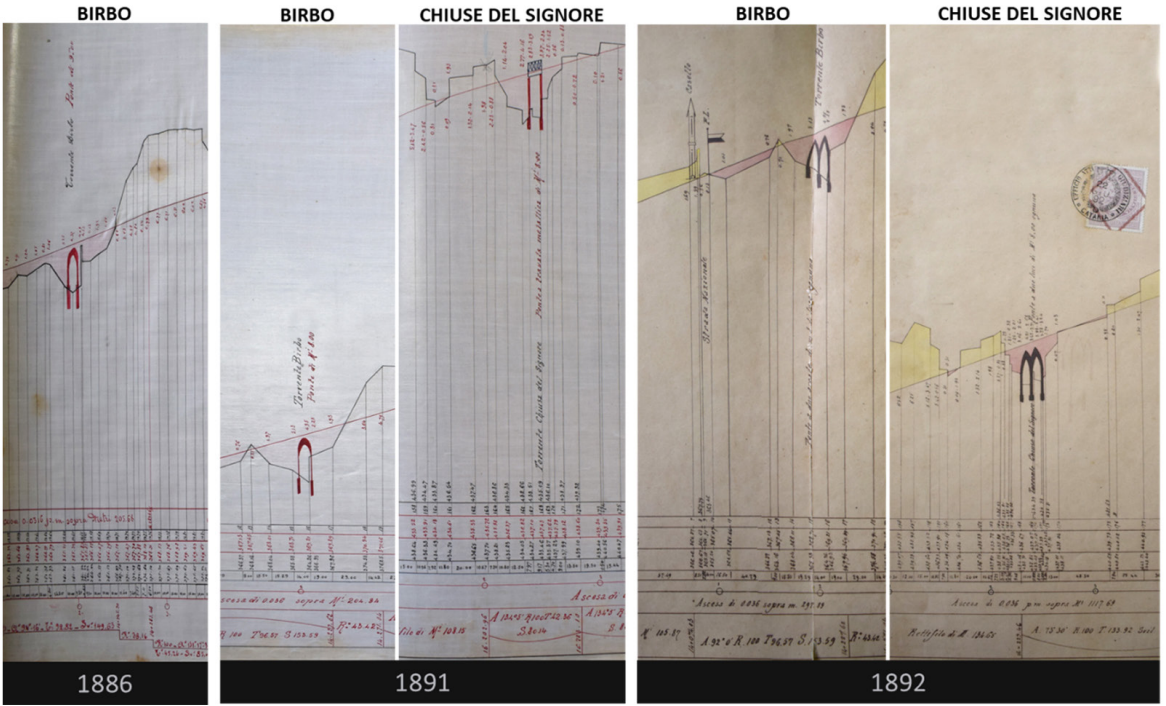

\section{The signalman's house n.92}

The signalman's house 92 (fig. 10) is located about one hundred metres from the bridge over the Birbo stream. The two-storey building is no longer in use but is in good condition and perfectly integrated with the surrounding urban context. The construction techniques are those of the late 19th century tradition for residential buildings, characterised by modest finishes and the use of construction materials from the Etnean area.

Historical and archival research

From a design point of view, the building consists of a "typified" housing unit (two rooms distributed in elevation, connected by a staircase) with other volumes added, probably to satisfy the needs of signalmen. The project of this "cell" constitutes a common denominator for other signalman's houses along the route and was found at the State Archive of Catania (fig. I la).
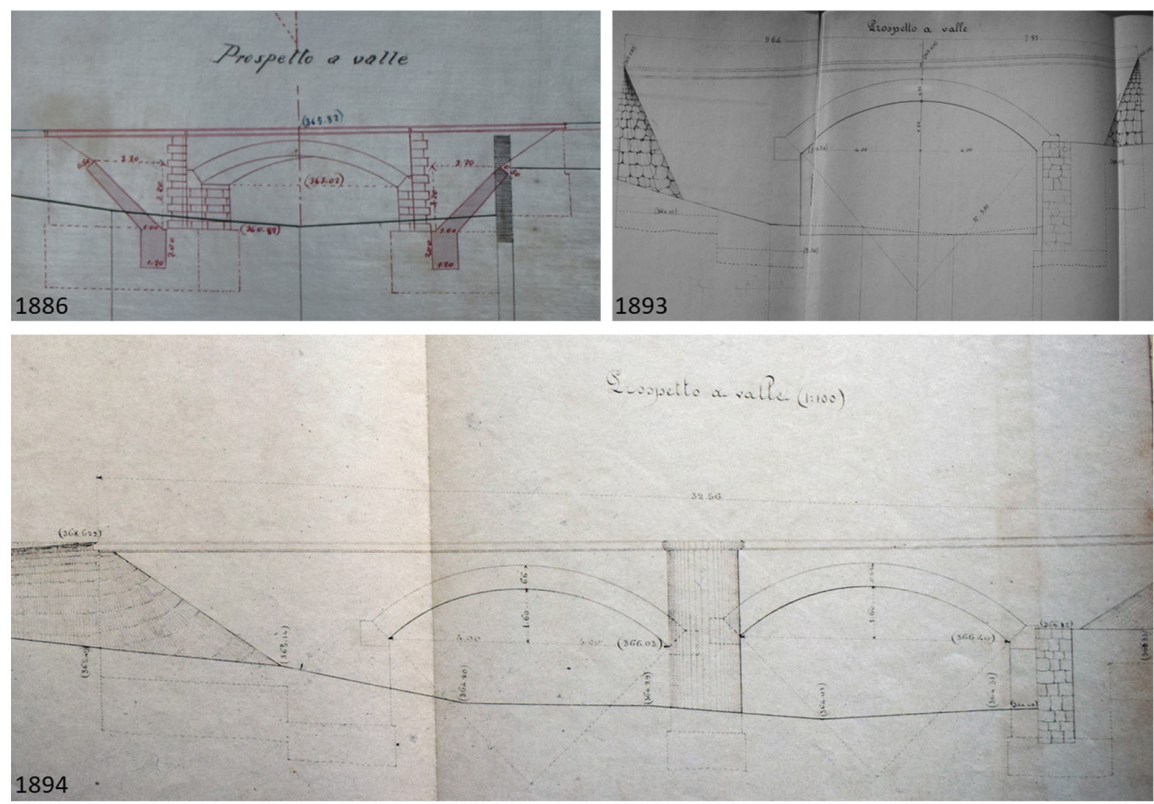
The analysis of the cadastral plans revealed, however, a different internal distribution, which presents, in addition to the module already described, a kitchen with bathroom, two other rooms, one of which is accessible only from the outside and a clearance room, no longer existing (fig. | | b).

\section{Digital survey}

Given the modest height and essential geometry of the building, it was decided to survey the building envelope using the BLK 360. Four scans were carried out, for a total of | 33,549,7 I I points, including a substantial part of the context (fig. I2).

Fig. 8. Location on the IGM I:25.000 of the signalman's house 93 (A) of the bridge over th Birbo river (B), of the bridge over the Chiuse del Signore river. C, below left, the bridge used as a reference for the design of the span of the bridge over the Birbo river.

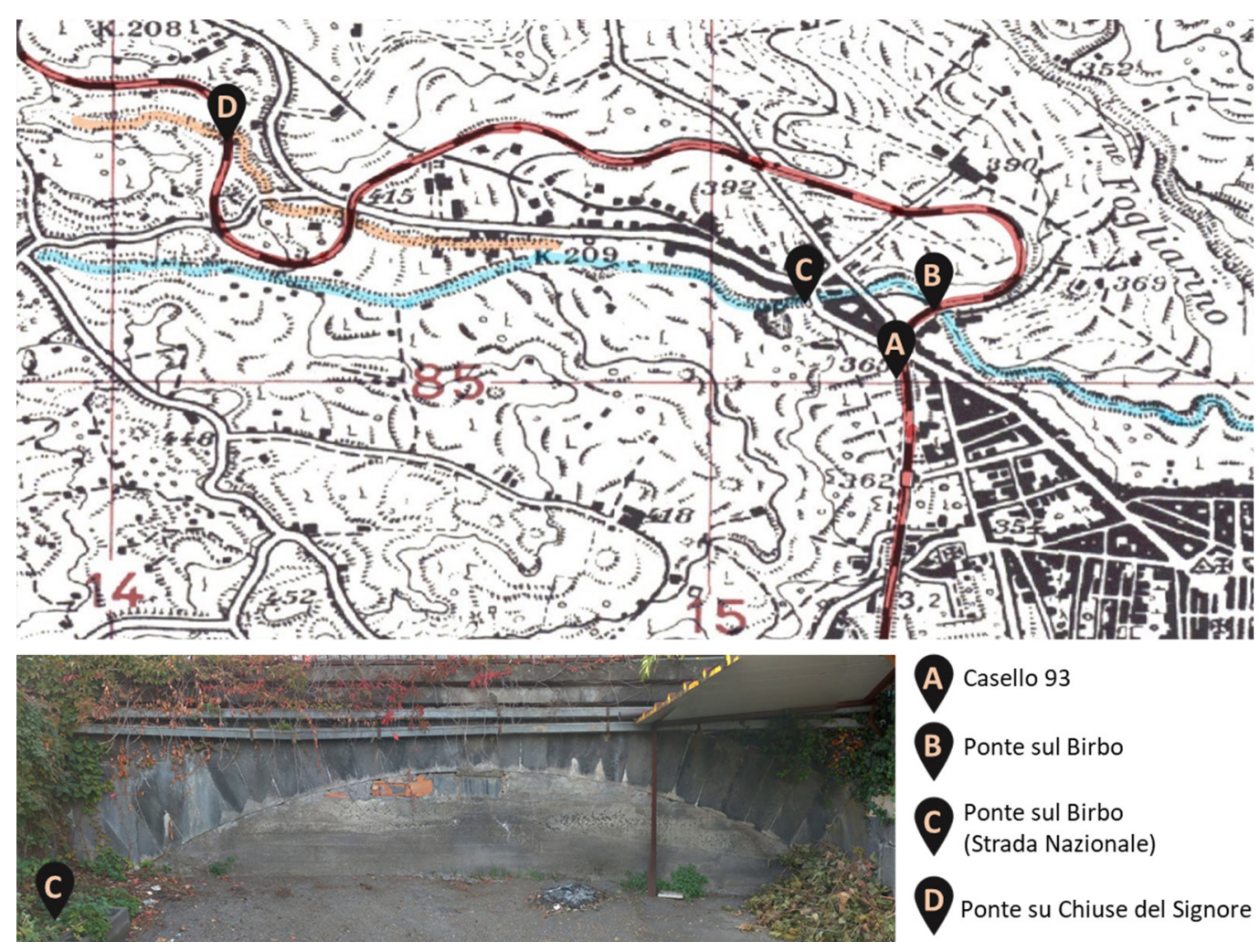

\section{Conclusions and future developments}

The research has brought to light the wide range of engineering and architectural works accompanying the Circumetnea railway line, evidence of a construction approach based on the principles of sustainability and respect for the territory. A retrospective reading of the design process compared with the actual condition allows hypotheses on the original orographic and environmental structures, now altered by intensive use of the land, providing new interpretations of these places' transformation over time.

The census and classification of the typologies of bridges, signalman's houses, and stations along the route, together with the digital surveying activities, provide a valuable and exhaustive knowledge base. This is necessary for the conservation, monitoring, enhancement, and regeneration of the urban environment. The research will proceed through the creation of contextualised-in-the territory information models, to connect the acquired data in a holistic perspective, which considers all the values characterising these episodes that mark the Etnean foothills landscape. 
Fig. 9. On top, laser scanning survey project right and bottom,

perspective views of the point cloud.

Fig. 10. The signalman's house 92 photographed from a viewpoint near the bridge over the Birbo river.

Fig. I I. a) On the left, the plan of the simple guardhouse, identified as the "standard" housing unit; b) On the right,

the cadastral plan of

the callhouse unde

the tolhouse under housing unit highlighted.

Fig. 12. The point cloud of the signalman's house 92 obtained through lase scanning survey.
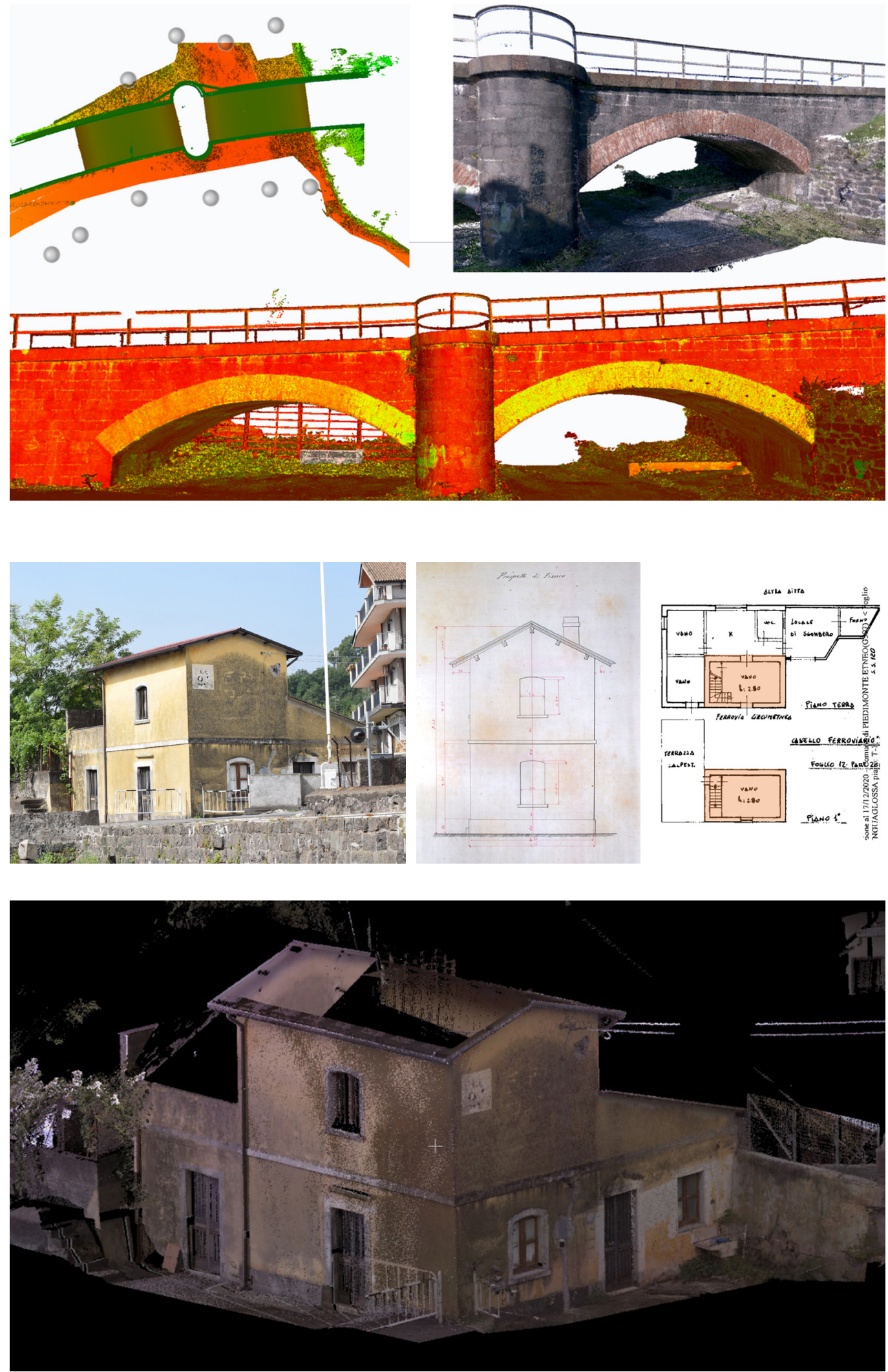


\section{Notes}

[I] Birbo river has as ramifications the streams 'Chiuse del Signore', 'Chiovazzi' and 'Girasa'.

[2] The profiles have a proportion of I:2000 for distances and 1:200 for heights.

\section{Credits}

Both authors made substantial contribution to the project. Raissa Garozzo has dealt with conceptualization, methodology, formal analysis, investigation, and data curation; Cettina Santagati has dealt with conceptualization, methodology and project supervision. For attribution, the authors wrote the paragraphs as follows: I,2,3 and 4 Raissa Garozzo, I and 5 Cettina Santagati.

\section{References}

Battino S., Donato C., Mele G. (20।8). Turismo sostenibile e culturale nelle aree interne del Nord Sardegna:Viaggi sul "trenino dei due mari". Trieste: EUT.

Bonanno L. (1999). Architetture del paesaggio: Ponti di Sicilia. Medina.

Cantalupi A. ( 1 884). La costruzione dei ponti e dei viadotti: trattato di architettura pratica. Milano:Vallardi.

Cresta A. (2019). Mobilità sostenibile e valorizzazione turistica delle aree interne: I treni storici tra identità e paesaggio <https://doi. org/10.13137/2282-572X/31729> (accessed 2021, February 3).

Curioni G. (1870). L'arte di fabbricare. Costruzioni civili, stradali e idrauliche. Torino: Augusto Federico Negro.

Dal Sasso P., Ottolino M. A. (20 I2). Greenway in Italy: Examples of projects and implementation. In Journal of Agricultural Engineering. n. 42 (I), 29. <https://doi.org/l0.408 I/jae.201 I.39> (accessed 2021, February 3).

Damiata D. (20I4). Digital Stereotomics: L'apparecchiatura elicoidale dei ponti obliqui. "Ponte a Grisignano di Zocco". Padova: Università degli Studi di Padova

Fadda S. (1915). Costruzione ed esercizio delle strade ferrate e delle tramvie. Album di costruzioni ferroviarie. Torino: UTET.

Inglese C., Paris L. (2020). Arte e tecnica dei ponti romani in pietra. Roma: Sapienza Università Editrice.

León-Robles C., Reinoso-Gordo J., González-Quiñones J. (2019). Heritage Building Information Modeling (H-BIM) Applied to A Stone Bridge. In ISPRS International Journal of Geo-Information. n. 8(3), I2I <https://doi.org/ I0.3390/ijgi8030 I 2 I> (accessed 2021, February 3).

Manganaro M. (20I I). Ponti e paesaggio rurale in Sicilia: Disegni e note/Bridges and the countryside in Sicily: Drawings and notes. In Disegnare. Idee Immagini n. 42, pp. 12-21.

Moschella A., Auricchiella A. (2017). Recupero e rifunzionalizzazione degli edifici ferroviari dismessi: Un'occasione per la ri-generazione del Parco Lineare tra Caltagirone e San Michele di Ganzaria. In Palma Crespo M., Gutiérrez Carrillo L., García Quesada R. (eds). ReUSO, Granada 2017: Sobre Una Arquitectura Hecha de Tiempo. Granada : EUG, vol.2 pp. 319-326.

Oppido S. (2020). Linee ferroviarie e valorizzazione del paesaggio. Orientamenti e sperimentazioni. In Diano D., Pinto M. R., (a cura di.) Reti ferroviarie e valorizzazione dei territori. Recupero, manutenzione e innovazione delle stazioni. Napoli: Scuola di Pitagora, pp. $173-187$.

Pavletits P. (202I). The Role and Possibilities of Hungarian Narrow-Gauge Railways in Tourism. In Kaposi Z., Rab V., Studies on Economic and Social History from Southern Transdanubia. vol. I, pp. I 32- I 39 <https://doi.org/ I 0.15 I 70/SESHST-0 I - I 5 > (accessed 2021, February 3)

Petino G., Wilson J., Knudsen D. C. (2018). Slow tourism in the ETNA Meso Region: Discovering the rural space with the Circumetnea railway. https://doi.org/I 0.1 3 I 40/RG.2.2.14288.56327> (accessed 202 I, February 3).

Sánchez-Rodríguez A. et al. (20 I8). Detection of structural faults in piers of masonry arch bridges through automated processing of laser scanning data. In Structural Control and Health Monitoring. n. 25(3). <https://doi.org/ I0.1002/stc.2 I $26>$ (accessed 2021, February 3).

Savini F. et al. (202I). Applications of Stratigraphic Analysis to Enhance the Inspection and Structural Characterization of Historic Bridges. In Infrastructures n. 6 (I). <https://doi.org/ 10.3390/infrastructures60 I 0007> (accessed 202I, February 3).

Tomasetti G. (2020). Un corridoio verde tra Langhe, Roero e Monferrato. La svolta "green" della linea ferroviaria dismessa tra Alba e Castagnole delle Lanze e il recupero dei fabbricati in disuso [PhD Thesis]. Università degli Studi di Genova.

Vaschetto D. (2017). Le più belle ferrovie secondarie d'Italia: /l Centro-Nord. Torino: Edizioni del Capricorno.

\section{Authors}

Raissa Garozzo, Università degli Studi di Catania raissa.garozzo@unict.it

Cettina Santagati, Università degli Studi di Catania, cettina.santagati@unict.it

To cite this chapter. Garozzo Raissa, Santagati Cettina (202I). Nuove prospettive sulla ferrovia Circumetnea: un viaggio tra archivi e rappresentazione digitale/Novel perspectives on the Circumetnea railway: a journey across archives and digital representation. In Arena A. Arena M. Mediati D. Raffa P. (a cura di). Connettere. Un disegno per annodare e tessere. Linguaggi Distanze Tecnologie. Atti del $42^{\circ}$ Convegno Internazionale de Docenti delle Discipline della Rappresentazione/Connecting. Drawing for weaving relationship. Languages Distances Technologies. Proceedings of the $42^{\text {th }}$ International Conference of Representation Disciplines Teachers. Milano: FrancoAngeli, pp. 1649 - 1668. 